УДК 786.6: 22.046 «VII»

DOI https://doi.org/10.31723/2524-0447-2019-29-2-6

Тетяна Миколаӥвна Маскович

ORCID: 0000-0003-4731-8350

доцент кафедри методики музичного виховання та диригування

ДВНЗ «Прикарпатський національний університет

імені Василя Стефаника»

tanysysja1980@gmail.com

\title{
БОГОРОДИЧНА ТЕМАТИКА У САКРАЛЬНІЙ МУЗИЦІ ГАННИ ГАВРИЛЕЦЬ: СТАРОВИННИЙ КАНТ ХVII СТ. «МАТИ МИЛОСЕРДА»
}

Мета статті полягає в спробі здійснення комплексного й системного аналізу основних параметрів концепцій $і$ стилістичних моделей, авторських національно-колоритних особливостей сакралізації образу Богородииі у творах духовної тематики Ганни Гаврилець на прикладі старовинного канта XVII cm. «Мати милосерда». Методологія роботи передбачає оновлення мистецтвознавчих досліджень щодо вивчення та залучення в мистецьку практику сакральних творів композиторки. У статті застосовуються методи інтонаційного й цілісного аналізу, історичний, історико-генетичний, текстологічний підходи - в розгляді специфіки хорової творчості Г. Гаврилець в ї̈ зумовленості з традиціями богородичних піснеспівів і літургійних богородичних текстів. Наукова новизна полягає у викладенні особливостей авторського підходу до змалювання теми Богородиці в духовній музиці Г. Гаврилець. Виокремлена майстерність комбінування Ганною Гаврилець найрізноманітніших засобів: авторської стилістики, де присутня типова для українського музичного мислення розлогість мелодики й мінливість ладо-гармонічних барв у варіаційному формотворенні, інтонаційної виразності хорової тканини, чергуванні рельєфних чи фонових функцій окремих партій за виразного утримання мелодичної функції у верхньому голосі, збагаченні фактурної тканини підголосковими розспівами, досягненні повноцінного розкриття твору-прототипу. У висновках узагальнено найголовніші моменти музичного сакрального мислення автора в духовному напрямку. Показано, як Ганна Гаврилець формує самобутній спосіб ресакралізації типових для національної творчості жанрів, не змішуючи водночас техніки різних мистецьких епох, зберігаючи власні межі самобутнього «чистого» стилю, характерною рисою якого виступає глибока проникливість у сутність українського міфологічного сприйняття та світовідчуття засобами сучасної музичної мови. Таким чином, духовна сакральність в авторському стилі Ганни Гаврилець

(C) Москович Т. М., 2019 
ілюструє свідоме сприйняття дійсності, де тісно переплелись традиціі та новації, вишуканий смак і сміливі композиторські рішення.

Ключові слова: Богородична тематика, піснеспів, Пресвята Богоматір, старовинний кант, Г. Гаврилець.

Maskovych Tatiana Mykolaivna, Assistant Professor at the Department of Music Education and Conducting Methods of the Vasyl Stefanyk Precarpathian National University

The marian theme in the sacred music of Hanna Havrylets: old canticle XVII century "The Mother of mercy"

The purpose of this article is an attempt to comprehensively and systematically analyse the main parameters of concepts and stylistic models, the authorial national and colourful features of the Holy Mother image sacralisation in the spiritual works of Hanna Havrylets: on the example of the old XVII century Canticle "The Mother of Mercy". The methodology of the work provides the renewal of art research concerning study and involvement in the artistic practice of the composer's sacred works. The article uses methods of intonation and holistic analysis, historical, historical-genetic, textual approaches - in considering the specifics of choral work G. Gavrilets in its conditionality with the traditions of the Virgin songs and liturgical texts. Scientific novelty is to highlight the peculiarities of the author's theme images of the Holy Mother in sacred music by H. Havrylets. Anna Gavrylets has mastered the skill of combining various means: author's stylistics, where there is a typical for Ukrainian musical thinking expansiveness of melody and variability of harmonic colors in variational formation, intonation expressiveness of choral fabric, alternation of relief or background functions of individual functions, enrichment of textured fabric with sub-vocal chants, achievement of full disclosure of the prototype work. In conclusion the main points of the musical sacred thinking of the author are summarised. It is shown how Anna Gavrylets forms an original way of re-sacralization of genres typical of national art, without mixing the techniques of different artistic epochs, preserving its own boundaries of the original "pure" style, characterized by deep insight into the essence of Ukrainian mythological perception and worldview. Thus, the spiritual sacredness in the author's style of Anna Gavrilets illustrates the conscious perception of reality, where traditions and innovations, refined taste and bold compositional decisions are closely intertwined.

Key words: Marian theme, chant, the Holly Mother, old Canticle, H. Gavrylets.

Маскович Татьяна Николаевна, доцент кафедры методики музыкального воспитания и дирижирования ГВНЗ «Прикарпатский национальный университет имени Василия Стефаника»

Богородичная тематика в сакральной музыке Анны Гаврилець: Старинный кант XVII cm. «Мать Милосердия»

Цель статьи состоит в попытке осуществления комплексного и системного анализа основных параметров концепций и стилистических моделей, авторских национально-колоритных особенностей сакрализа- 
ции образа Богородицы в произведениях духовной тематики Анны Гаврилец на примере старинного канта XVII века «Мать Милосердия». Методология работы предусматривает обновление искусствоведческих исследований по изучению и привлечению в художественную практику сакральных произведений композитора. В статье применяются методы интонационного и иелостного анализа, исторический, историко-генетический, текстологическим подходы-в рассмотрении спеиифики хорового творчества Г. Гаврилеи в ее обусловленности традициями богородичных песнопений и литургических богородичных текстов. Научная новизна заключается в освещении особенностей композиторского воплощения темы Богородицы в духовной музыке А. Гаврилеи. В выводах обобщены главные моменты музыкального сакрального мышления автора в духовном направлении. Показано, как Анна Гаврилеи, формирует самобытный способ ресакрализации типичных для национального творчества жканров, не смешивая при этом техники различных художественных эпох, сохраняя собственные границы самобытного «чистого» стиля, характерной чертой которого выступает глубокая проникновенность в сущность украинского мифологического восприятия и мироошущения средствами современного музыкального языка. Таким образом, духовная сакральность в авторском стиле Анны Гаврилеи, демонстрирует сознательное восприятие действительности, где тесно переплелись традиции и новации, изысканный вкус и смелые композиторские решения.

Ключевые слова: Богородичная тематика, песнопение, Пресвятая Богоматерь, старинный кант, А. Гаврилець.

Актуальність теми дослідження. Тематика образу Богородиці, як беззаперечної опікунки потребуючих та неустанної допомоги для вірних, присутня у творчості майже усіх композиторів сьогодення. Одним із головних чинників розмаїття репертуару богородичних піснеспівів вважається мистецька вартістність літургійних богородичних текстів, в яких Пресвята Діва Марія зображена в образі не лише Могутньої Володарки, Цариці Небесної, але й милосердної заступниці, яка переживши великі душевні муки стала Матір'ю для всього людства.

Мета статті полягає в спробі здійснення комплексного й системного аналізу основних параметрів концепцій і стилістичних моделей, авторських національно-колоритних особливостей сакралізації образу Богородиці у творах духовної тематики Ганни Гаврилець на прикладі старовинного канта XVII ст. «Мати милосерда».

Наукова новизна полягає у викладенні особливостей авторського підходу до змалювання теми Богородиці в духовній 
музиці Г. Гаврилець. Виокремлена майстерність комбінування Ганною Гаврилець найрізноманітніших засобів: авторської стилістики, де присутня типова для українського музичного мислення розлогість мелодики й мінливість ладо-гармонічних барв у варіаційному формотворенні, інтонаційної виразності хорової тканини, чергуванні рельєфних чи фонових функцій окремих партій за виразного утримання мелодичної функції у верхньому голосі, збагаченні фактурної тканини підголосковими розспівами, досягненні повноцінного розкриття твору-прототипу.

Основний зміст роботи. Український богослов та літургіст отець Петро Крип'якевич налічує понад двадцять богородичних піснеспівів для однієї доби за Октоїхом, до яких у недільному богослужінні ще додається близько двадцять малих гимнів й богородичний канон [10, с. 134-149]. «Це і є та основа, що на ній, і передусім на ній, закладено й потужно розгорнуто ту дивовижну і справді величаву на честь Блаженної Діви Богородиці гімнографію, що складає не лише чималу частину святої гімнографія, але також - хай нам буде дозволено так мовити є і головною для неї, i “живою душею” і стала мов би першими строфами того нескінченного гімну на честь Богородиці, що з тих часів продовжується у віках» [15, с. 52].

Також саме богородичний жанр був так званим завершенням окремих служб, великих чи малих літургійних циклів піснеспівів. Відомі дослідники, такі як Дмитрій Ліхачов, Дмитро Чижевський, Михайло Мурьянов та інші у своїх працях вказували на важливу роль літургійної поезії у створенні певного окремого середовища, в якому творилися семантичні та лексичні моделі, а також деякі усталені формальні прийоми. Так встановлювалася нова образна система, де поступово особливого звучання набувала тема Богоматері, що проникла у глибини жанрового розмаїття української літератури.

Характерним прикладом відновлення одвічно-давнього жанру за органічності його входження у неординарну сакральну містерію дійства «Золотий камінь посіємо» є обробка старовинного канту XVII ст. «Мати милосерда» для солістки та хору хлопчиків із четвертого розділу «Доба козацтва», який одразу занурює слухача у певний окремий часовий вимір, захоплюючи своєю мереживною красою та лаконічністю. Вибір саме цього твору серед масиву писемно-пісенних джерел музично-українського Бароко, навіть поза концепцією конкретної 
частини дійства, невипадковий саме з точки зору актуальних для сучасності архетипів української культури. До них належать і період створення твору, і його автор (духовний світоч української землі, людина європейської культури, письменник-енциклопедист Димитрій (Дмитро) Туптало, визнаний святим у 1757 р.), і обраний композиторкою жанр (кант як одне 3 уособлень музичної хорової культури доби козацького Бароко, творчості «мандрованих» дяків і спудеїв КиєвоМогилянської академії, а не псальма, як сольний, хоча не менш репрезентативний, жанр), що сприймається вже як один із феноменів національної творчості.

На перший погляд, канти - не дуже складні для виконання духовні твори, проте в процесі роботи сучасним молодим виконавицям є дуже непросто у своєму співі передати той первинний зміст, що закладений у біблійних текстах. I тут відчувається спорідненість канту та церковних псальмів: в них слово несе інформацію, яку спочатку потрібно глибинно осягнути, відчути своїм серцем, зробити певні власні акценти, а тоді вже «через серце та душу» донести їі до найрізноманітнішого слухача.

Вартістність теми Богородиці притаманна не тільки для паралітургічного, а й церковно-співочого пласту української духовно-музичної творчості: «В українській гімнографії тема Пресвятої Богородиці займає одне з чільних місць і впродовж декількох століть ініціювала три основні образні сфери: ліричну, прославну та страсну. Лірична образність була тісно пов'язана з темою Богоматері, чудесним народженням Iсуса i умиленієм Матері над дитинкою. Прославні піснеспіви возвеличували Пресвяту Богородицю і вітали їі як земну Царицю. Тема страждання, пієти, плачу Пресвятої Богородиці тісно перепліталася $з$ темою страстей Христових» [15, с. 76]. Сам образ Богородиці належить до давніх сакральних символів-оберегів душі окремого представника нації та всього українського народу, чим пояснюється тісне зімкнення різних пластів пісенності, широке звернення до богородичної тематики в композиторській творчості тощо. Обравши цю псальму Димитрія Ростовського (Дмитра Тупало) як взірець козацької молитовної пісенності, композиторка водночас «втягнула» в асоціативний ряд і інші не менш репрезентативні твори, зокрема знаменитий кант в аранжуванні М. Лисенка «Пречистая Діво-Мати Руського краю», популярність якого доте- 
пер вважається найвищим рівнем у виконавському хоровому репертуарі.

3 текстом псальми Ганна Гаврилець працювала цілком в традиціях хорового концерту. Це цікава і промовиста паралель: жанр народної паралітургічної поезії - псальма - є основою канту Г. Гаврилець, а псалом - жанр високої біблійної поезії - основою високого професійного жанру хорового концерту. Композиторка досить довільно та авторсько-сміливо обирає вірші, ніби граючись, створює свій власний індивідуалізований смисловий ряд. 3 тексту-основи авторкою було вилучено два куплети. Один з них (в зразку Дмитро Туптало другий від початку) надавав образ-метафору лютого звіра, від якого позбавляє допомога Богородиці:

Он, лютый, рыкает,

Бедна мя хищает.

Скоро, скоро твоя помощь

От того избавляет.

Другий куплет канту містить так звану згадку про невідомість для людини іiі дня смерті та благання в цей трагічний для неї час про особливе заступницто:

Не вем аз кончину,

Дня того годины,

K тебе, к тебе, всех иарице,

Очи мои выну.

Внаслідок цього кант у варіанті Г. Гаврилець наділений винятковою узагальненістю певного епіко-ліричного вияву молитовного благання, позбавленого трагічних емоцій, поміркованого неспокою, це виокремлено завдяки створенню репризного ефекту - повторення початкового куплету наприкінці всього твору.

Стилістика ж канту «синтезується 3 технікою багатоголосної обробки народної пісні в традиціях лисенківської школи» [8, с. 83]. Джерелом та основою усієї музичної тканини є мелодія псальми - розлога (навіть за умови двотактового фразування), мінлива інтонаційно (адже у структурі присутні лише два мотиви, що мають ідентичну структуру, та вони слугують певною ланкою секвенціï) та при цьому із вираженим опорним звуком - першим щаблем ладу. Цікавою $€$ й ритмічна організація: тотожність початкової та кінцевої фраз зумовлює ефект «замикання», а ритмічний малюнок у другому такті кожної фрази (за винятком третьої) за інтона- 
ційної тотожності (низхідна в. 2) створює фон мелодичного римування.

Ганна Гаврилець зберігає мелодію майже незмінною упродовж усього музичного твору, відтак основним засобом розвитку слугує фактура, в якій щораз по новому простежуються поєднання принципів лінійності та функційності. Ганна Гаврилець не одразу використовує типову кантову фактуру: перша варіація демонструє своєрідний «натяк» на розвинуте багатоголосся - у других дискантів з'являється мелодично нерозвинена, гармонічно функційна лінія. У наступних варіаціях мелодично розвинуті підголоски в жодному випадку за тривалостями не створюють типової кантової фактури, хоча нижній голос створює гармонічну опору, а в середніх голосах іноді трапляються елементи втори. Вільне мереживо голосів змальовує спільне багатоголосся, а виділення сольного голосу (в «автентичному» виконанні розмежування соло у виконанні народної артистки України - Ніни Матвієнко та хору хлопчиків створює надзвичайно сильний тембрально-контрасний ефект), згущення і розрідження фактури. Важливим семантичним засобом при вкрапленні нового мотиву - моління до Христа («Руці да воздіну») - $є$ тональні співтавлення $E$-Dur / G-Dur, що сприймається як певне просвітлення, що веде до насиченої, фактурно багатої кульмінації (шестиголосся). Нетипове звучання сольного голосу та дискантових партій формує ефект особливої прозорості, внаслідок чого дві початкові фрази мимоволі сприймаються як тиха кульмінація із розгортанням у заключному тріумфальному проголошенні:

От лютаго врага злаго

Храниши мя всегда.

Наукова новизна дослідження полягає у виокремленні майстерного комбінування Ганною Гаврилець найрізноманітніших засобів: авторської стилістики, де присутня типова для українського музичного мислення розлогість мелодики та мінливість ладо-гармонічних барв у варіаційному формотворенні, інтонаційної виразності хорової тканини, чергуванні рельєфних чи фонових функцій окремих партій за виразного утримання мелодичної функції у верхньому голосі, збагаченні фактурної тканини підголосковими розспівами, досягненні повноцінного розкриття твору-прототипу. А відповідно до концепції дійства «Г. Гаврилець створила яскраву, сповнену українського колориту стилізацію щиросердної молитви» [8, с. 83]. 
«Життя культури не адекватне зміні старого на нове, минулого на прийдешнє, воно не підпадає взагалі під стрілу часу, бо акумулює потенціал всіх часів» [10, с. 159]. Таким чином всі розглянуті риси в комплексі набувають значення загальних ознак творчості Ганни Гаврилець, кожного разу набуваючи все нових, неординарних відтінків: єдність семантико-синтаксичного комплексу, заснованому поєднанні характерних рис гуртового багатоголосся, стилістика окремих показових для тих чи інших епох жанрів, класичних для української музики принципів аранжування фольклорної пісенності, змалювання принципів композиторської класики та оригінального авторського мислення, що дає змогу систематизувати вище проаналізоване, зробивши певні висновки. Не змішуючи техніки різних мистецьких епох, працюючи в межах самобутнього «чистого» стилю, Ганна Гаврилець формує самобутній спосіб ресакралізації типових для національної творчості жанрів.

Таким чином, «в осягненні прадавніх основ української народної духовної традиції Ганну Гаврилець вирізняє глибока проникливість у сутність українського міфологічного сприйняття і світовідчуття. Композиторка інтерпретує першотворчі елементи засобами сучасної музичної мови, не порушуючи первинної Гармонії» [1, с. 208-219]. Підсумовуючи, варто зауважити, що духовна сакральність в авторському стилі Ганни Гаврилець ілюструє свідоме сприйняття дійсності, де тісно переплелись традиції та новації, вишуканий смак та сміливі композиторські рішення.

\section{СПИСОК ЛІТЕРАТУРИ}

1. Бенч-Шокало О. Актуалізація звичаєвої традиції в сучасній музичній культурі України (композиторська творчість, виконавство, суспільні форми буття) : дис. ... докт. мист. Київ, 2008. 307 с.

2. Герасимова-Персидська Н. Хоровий концерт на Україні в XVII-XVIII ст. Київ : Муз. Україна, 1978. 184 с.

3. Грица С. Кореспонденція мелосу духовних віршів, псалмів і дум в усному епічному виконанні. Етнологія, фольклористика: Доп. та повідомлення : IV Міжнар. конгрес україністів. Кн. 1. Одеса-Київ, 2001. C. $317-324$.

4. Етнічні архетипи в релігійному житті українців. URL: http:// revolution.albest.ru/religion/ 00300624-ohtml.

5. Забияко А. Сакральный символ. Религиоведение : энциклопедический словарь / под ред. А. Забияко, А. Красникова, Е. Элбакян. Москва : Академический Проект, 2006. С. 945-946. 
6. Израилев Аристарх. Псалмы или духовные канты, Святителя Димитрія, Митрополита Ростовскаго. Москва, 1891. 43 с.

7. Интертекстуальность. Академик : веб-сайт. URL: http://dic.academic.ru/dic.nsf/enc_culture/

8. Катунян М. Сакрально-обрядовые архетипы в современной композиции: новый синкретизм. Новое сакральное пространство. Духовные традиции и современный культурный контекст : материалы научной конференции ; Научные труды Московской государственной консерватории им. П.И. Чайковского. Вып. 47. Москва : Московская консерватория, Редакционно-издательский отдел, 2004. С. 162-180.

9. Костюк Н. Ескіз до характеристики (аспекти сакрального у музиці Ганни Гаврилець). Студії мистецтвознавчі. Київ, 2004. Число 2 (6). С. 82-93.

10. Кримський С. Історія та метаісторія. Запити філософських смислів. Київ, 2008. 717 с.

11. Крип'якевич П. Про Богородичну гимнографію у грецькій Церкві. Калофонія : науковий збірник з історії церковної монодії та гімнографії. Львів, 2010. Ч. 5. С. 114-165.

12. Krypjakevych P. De hymnographia Mariana in Ecclesia Graeca. Записки НТШ. Ч. 1. Т. СXXI. 1914. P. 1-62; Elenchus maiorum hymnorum Deiparae. ЗНТШ. Ч. 2. T. XXIII-XXIV. 1917. P. 1-56.

13. Куровська I. Жанрова атрибуція канту як духовного піснеспіву (на прикладі кантів Димитрія Туптала). Проблеми взаємодіï мистеитва, педагогіки та теорії і практики освіти. 2011. Вип. 32. C. 59-68. URL: http://nbuv.gov.ua/UJRN/Pvmp_2011_32_8.

14. Український кант XVII-XVIII століть / упор., вступ. ст., прим. Л. Івченко. Київ : Муз. Україна, 1990. 199 с.

15. Ясіновський Ю. Богородичний культ в українській церковній монодії. Вісник Львівського університету ім. Івана Франка. Серія «Мистеитвознавство». 2003. Вип. 3.С. 76-83.

16. Труссон П. Сакральное и миф. URL:http://www.nationalism. org/vvv/trusson-sacral-and-myth.htm.

17. Шелюто В. Проблема сакрального як світоглядна. Наука. Релігія. Суспільство. 2010. № 4. С. 94-101.

\section{REFERENCES}

1. Bench-Shokalo, O. (2008) Aktualizatsiya zvychayevoyi tradytsiyi v suchasniy muzychniy kulturi Ukrayiny (kompozytorska tvorchist, vykonavstvo, suspilni formy buttya). Doctor's thesis. Kyiv [in Ukrainian].

2. Herasymova-Persydska, N. (1978) Khorovyy kontsert na Ukrayini v VII-VIII st. Kyyiv: Muz. Ukrayina [in Russian].

3. Hrytsa, S. (2001) Korespondentsiya melosu dukhovnykh virshiv, psalmiv i dum $\mathrm{v}$ usnomu epichnomu vykonanni. IV Mizhnar. konhres ukrayinistiv. Odesa. Kn. 1: Etnolohiya, folklorystyka: Dop. ta povidomlennya. Odesa-Kyyiv, S. 317-324 [in Ukrainian].

4. Ethnic archetypes in the religious life of Ukrainians. URL: http://revolution.albest.ru/religion/ 00300624-ohtml [in Ukrainian]. 
5. Zabyyako, A. (2006) Sakralnyy symvol Relyhyovedenye: йntsykl. slovar [pod red. A.P. Zabyyako, A.N. Krasnykova, E.S. Élbakyan]. Moskva: Akademycheskyy Proekt, S. 945-946 [in Russian].

6. Yzraylev Arystarkh (1891) Psalmy yly dukhovnye kanty, Svyatytelya Dymytriya, Mytropolyta Rostovskaho. Moskva [in Russian].

7. Intertekstual'nost' URL: http://dic.academic.ru/dic.nsf/enc_ culture/[in Russian].

8. Katunyan, M. (2004) Sakral'no-obryadovyye arkhetipy v sovremennoy kompozitsii: novyy sinkretizm. Novoye sakral'noye prostranstvo. Dukhovnyye traditsii i sovremennyy kul'turnyy kontekst: materialy nauchnoy konferentsii Nauchnyye trudy Moskovskoy gosudarstvennoy konservatorii im. P. I. Chaykovskogo. Vyp. 47. Moskva: Moskovskaya konservatoriya Redaktsionno-izdatel'skiy otdel. S. 162-180 [in Russian].

9. Kostyuk, N. (2004) YeskHz do kharakteristiki (aspekti sakral'nogo u muzitsh Ganni Gavrilets') Studíi mistetstvoznavchH. Kiïv, 2004. Chislo 2 (6). S. 82-93 [in Ukrainian].

10. Krims'kiy, S. (2008) Hstornya ta metahstornya. Zapiti fHlosofs'kikh smislhv. Kiî̀ [in Ukrainian].

11. Krypyakevych, P. (2010) Pro Bohorodychnu hymnohrafiyu u hretskiy Tserkvi. Kalofoniya: naukovyy zbirnyk z istoriyi tserkovnoyi monodiyi ta hymnohrafiyi. Lviv, CH. 5. S. 114-165 [in Ukrainian].

12. Krypjakevych, P. $(1914,1917)$ ch. 1: De hymnographia Mariana in Ecclesia Graeca. Zapysky NTSH. T. CXXI. - P. 1-62; ch. 2: Elenchus maiorum hymnorum Deiparae. ZNTSH. T. XXIII-XXIV. - P. 1-56 [in Latin].

13. Kurovska, I. (2011) Zhanrova atrybutsiya kantu yak dukhovnoho pisnespivu (na prykladi kantiv Dymytriya Tuptala). Problemy vzayemodiyi mystetstva, pedahohiky ta teoriyi i praktyky osvity. Vyp. 32. S. 59-68. URL: http://nbuv.gov.ua/UJRN/Pvmp_2011_32_8 [in Ukrainian].

14. Ukrayinskyy kant XVII-XVIII stolit (1990) [upor., vstup. st., prym. L.V. Ivchenko]. Kyyiv: Muz. Ukrayina [in Ukrainian].

15. Yasinovskyy YU. (2003) Bohorodychnyy kult v ukrayinskiy tserkovniy monodiyi. Visnyk Lvivskoho universytetu im. Ivana Franka: Seriya mystetstvoznavstvo.Vyp. 3. S. 76-83 [in Ukrainian].

16. Trusson, P. Sakralnoey myf. URL: http://www.nationalism.org [in Russian].

17. Shelyuto, V. (2010) Problema sakralnogo yak svItoglyadna. Nauka. RelIgIya. SuspIlstvo. № 4, S. 94-101 [in Ukrainian]. 